\begin{tabular}{|l|l|l|l|l|l|}
\hline J. Tek. Ling & Vol. 12 & No. 1 & Hal. $75-84$ & Jakarta, Januari 2011 & ISSN 1441-318X \\
\hline
\end{tabular}

\title{
DAMPAK BUDIDAYA PERTANIAN INTENSIF TERHADAP KUALITAS AIR PERMUKAAN DESA KANIGORO KECAMATAN NGABLAK KABUPATEN MAGELANG
}

\author{
Wage Komarawidjaja \\ Peneliti di Pusat Teknologi Lingkungan, \\ Badan Pengkajian dan Penerapan Teknologi
}

\begin{abstract}
Kanigoro at Ngablak Sub-District in Magelang is one of the Villages which is topographically lower than the adjacent village in the same sub-district. The main activity of village inhabitant is farmer in intensive agriculture that is indicated by a lot of fertilizer and pesticide utilization. Therefore, the exceeding dosage of fertilizer and pesticide in plant cultivation could become an anxious environmental problem due to the high concentration of them in springs water that they called as Tuk and river water more than the quality standard of National regulation.

Based on Data analysis, it can be concluded that laboratory analysis result of water quality in the village Kanigoro, generally still meet the quality standard. This is showed by the concentration of heavy metals (As, Cu, Cd, Hg, Zn and $\mathrm{Fe}$ ) and pesticides (Aldrin, BHC, Chlordane, DDT, Dieldrin, Endrin, Heptachlor, Heptachlo epoxide, Lindane, Methoxychlor and Toxaphene), except for some points sampling contain heavy metals plumbum $(\mathrm{Pb})$ exceeded water quality standard of the Minister of Health (Depkes) and Government Regulation Class I (raw water) of PP 82/2001. While the density of microbial total coliform and E. coli detected abundant compare to the water quality standard of the Minister of Health, particularly for the use of water as raw water or clean water. However, it is possible to utilize water directly for agriculture and fish farming activities and the use for drinking water after cooked first
\end{abstract}

Keywords: water quality, heavy metals, pesticides, microbes.

\section{PENDAHULUAN}

\subsection{Latar Belakang}

Kecamatan Ngablak, Kabupaten Magelang, Provinsi Jawa Tengah, secara geografis terletak pada kordinat $110^{\circ} 20^{\prime}$
50" sampai dengan $110^{\circ} 26^{\prime} 15^{\prime \prime}$ Bujur Timur dan $7^{\circ} 20^{\prime} 30^{\prime \prime}$ sampai dengan $7^{\circ} 26^{\prime} 00^{\prime \prime}$ Lintang Selatan, dengan ketinggian wilayah antara $203-1.378$ meter diatas permukaan laut (Gambar 1). Luas wilayah Kecamatan 
ini sekitar 43,78 km2, yang meliputi 16 Desa, yaitu desa Ngablak, Jogonayan, Tejosari, Sumberejo, Girirejo, Pandean, Genikan, Bandungrejo, Madyogondo, Jogoyasan, Keditan, Magersari, Kanigoro, Selomirah, Pagergunung dan Seloprojo (BPS Kab. Magelang, 2005). ${ }^{1)}$ Kecamatan ini, di sebelah Timur berbatasan dengan Kec Ngampel dan Selo Kab. Boyolali, di sebelah Barat berbatasan dengan $\mathrm{Kec}$ Grabag Kab Magelang, di sebelah Utara berbatasan dengan Kec Banyubiru dan Kec. Getasan Kab Semarang dan di sebelah Selatan berbatasan dengan Kec. Pakis Kab. Magelang (BPS Kabupaten Magelang, 2005). ${ }^{1,2)}$

Kecamatan ini memiliki topografi yang cukup bervariasi, mulai dari datar, bergelombang, curam, sampai sangat curam. Daerah dengan topografi datar dan bergelombang, sebagian besar digunakan untuk kegiatan pertanian dan lokasi permukiman, sedangkan topografi yang curam dan sangat curam merupakan kawasan perbukitan dan sebagian besar kawasan hutan yang berfungsi untuk melindungi kawasan sekitarnya yang lebih rendah. ${ }^{2,3)}$ Hal tersebut didukung oleh data BPS (tahun 2005), yang menyebutkan luas lahan yang digunakan sebagai lahan pertanian yakni lahan persawahan $(3 \%)$ dan lahan tegalan/kebun $(70 \%)$, sisanya sebagai lahan pekarangan $(10 \%)$, hutan $(12 \%)$ dan penggunaan lain-lain $(5 \%) .{ }^{1)}$ Lahan pertanian yang tersedia tersebut, didominasi oleh kegiatan budidaya palawija dan hortikultura yang dilakukan secara intensif, dimana kegiatan pemupukan dan penyemprotan pestisida sangat berperan dalam mendukung produksinya. ${ }^{3)}$

Dengan sifat pestisida yang toksik dan persisten, penggunaan pestisida yang tidak terkontrol dikawatirkan akan membebani lingkungan dan menurunkan kesehatan

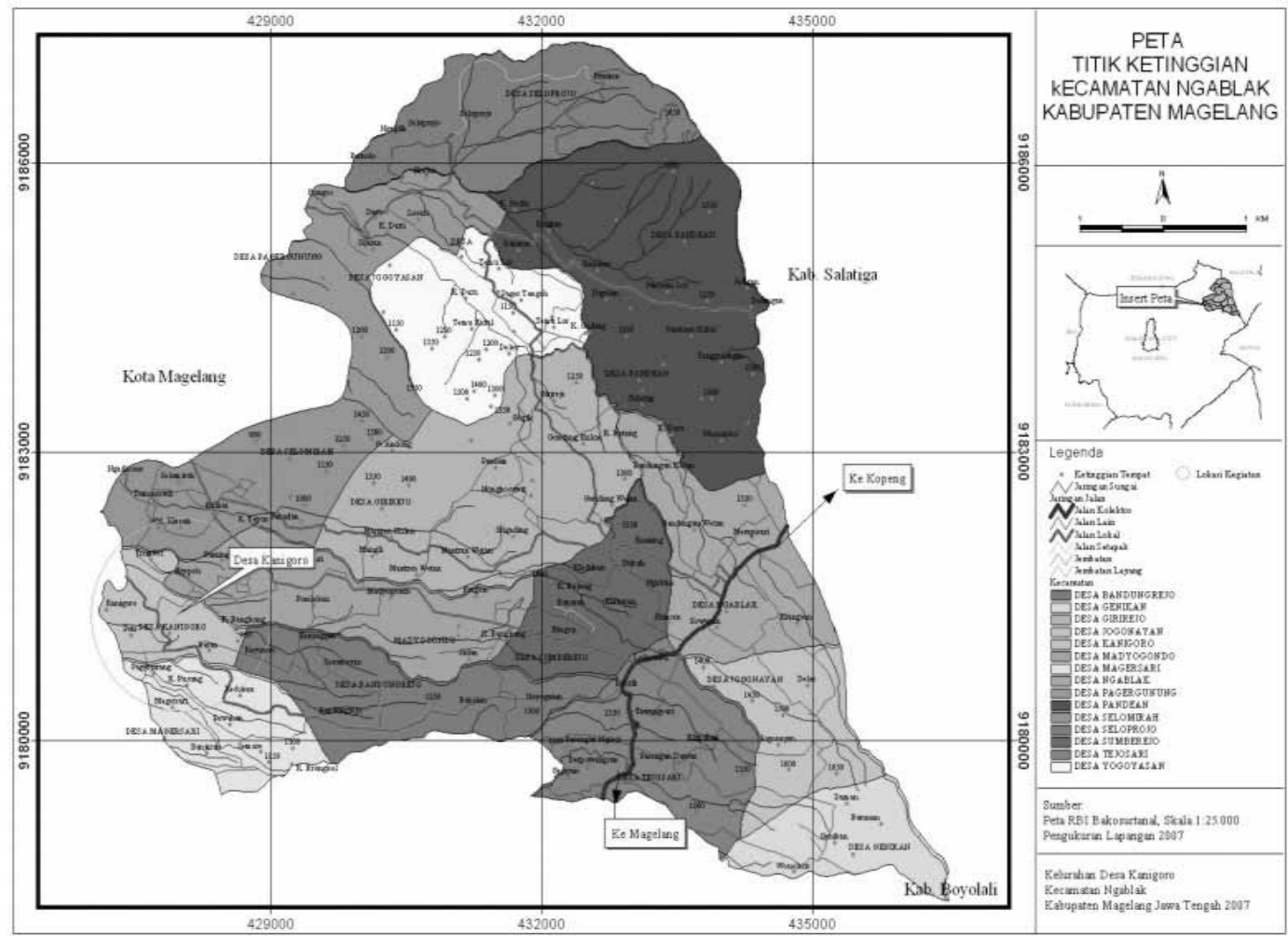

Gambar 1. Peta Batas Desa dan Ketinggiasn di Kecamatan Ngablak, Kab Magelang 
lingkungan. Oleh karena itu pemanfaatannya perlu diwaspadai, mengingat beberapa laporan menyebutkan bahwa masyarakat petani di Kecamatan Ngablak lebih dari $70 \%$ diindikasikan terpapar oleh pestisida dari kegiatan pertanian yang mereka lakukan.,5,6)

Desa Kanigoro adalah salah satu Desa di Kecamatan Ngablak, Kabupaten Magelang, yang bertetangga dengan desa Bandungrejo di sebelah timur, desa Madyogondo di sebelah utara dan desa Magersari di sebelah selatan. Berdasarkan peta topografi, desa Kanigoro terletak lebih rendah dibanding dengan ketiga Desa yang disebutkan diatas.2) Dengan demikian, secara hidrologis, desa Kanigoro mendapat aliran air berasal dari desa Bandungrejo, Madyogondo dan Magersari, sehingga apapun yang terkandung dalam air yang masuk desa Kanigoro, diduga akan membawa berbagai bahan kimia sumber limbah yang berasal dari kegiatan pertanian di kawasan desa Bandungrejo, Madyogondo dan Magersari. ${ }^{3)}$

Oleh karena di Desa Kanigoro diduga selain menerima cemaran dari kegiatan pertanian di Desanya sendiri, juga diduga mendapat imbuhan dari kegiatan pemukiman, pertanian dan perkebunan Desa lain. Daerah-daerah yang terkena pengaruh pencemaran ini dapat membahayakan kehidupan manusia dan biota lain.

\subsection{Sumber Air Penduduk}

Berdasarkan peta hidrologi, jaringan sungai dan arah aliran air tanah di Kecamatan Ngablak disajikan pada peta Gambar 2, berpola dendritik dan bersifat intermitten, dimana pada musim kemarau kondisinya tidak ada airnya, sedangkan pada musim penghujan, terdapat aliran air tetapi tidak

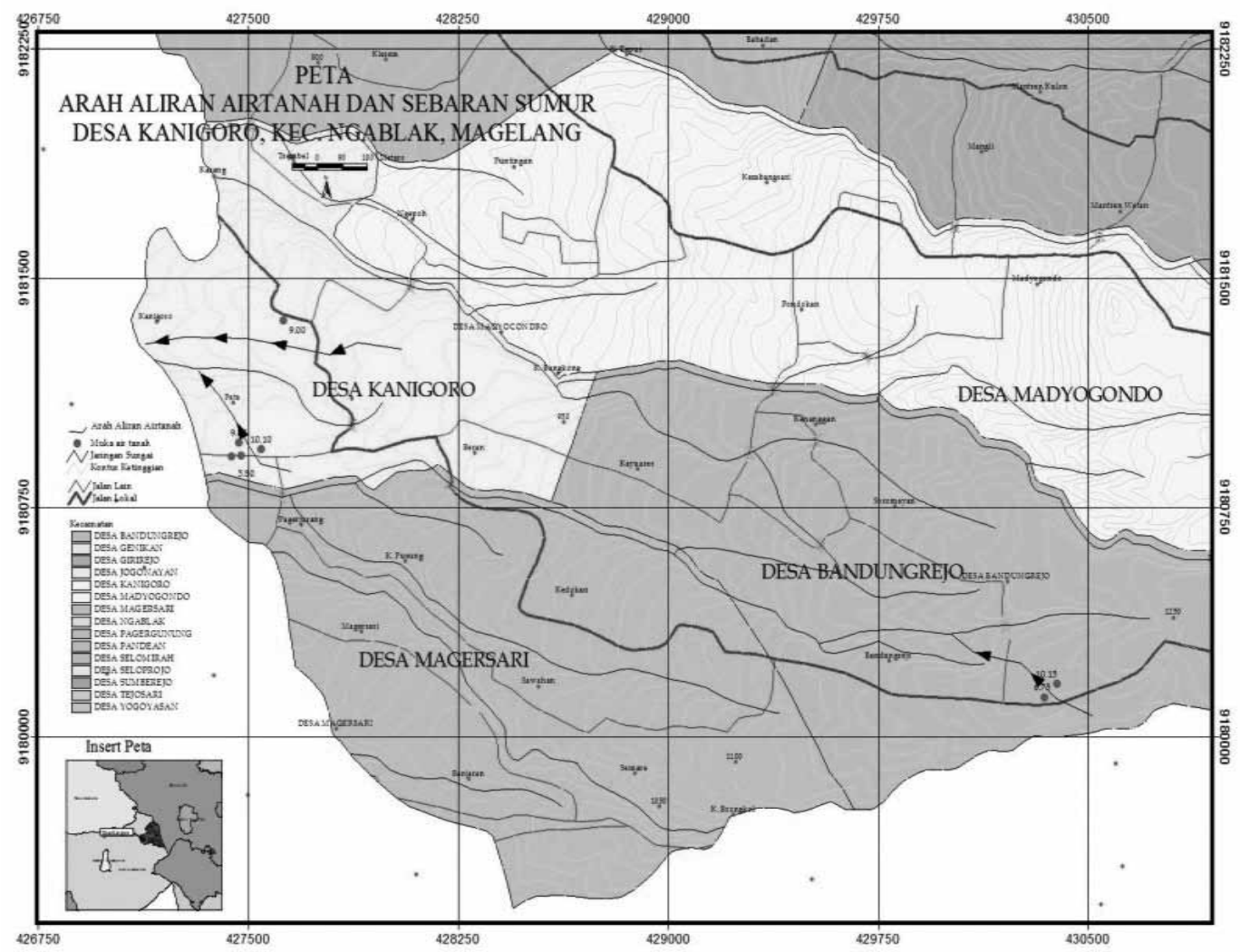

Gambar 2. Peta Jaringan Sungai dan Arah Aliran Air Tanah di Kecamatan Ngablak, Kab Magelang 
bisa bertahan lama karena tingkat porositas yang tinggi, sehingga air sungai tidak bisa dijadikan sumber air untuk kebutuhan penduduk. ${ }^{2,7)}$

Untuk memenuhi kebutuhan air, beberapa penduduk di desa Kanigoro dan sekitarnya membuat sumur gali, tetapi sebagian besar penduduk mencari sumber mata air disekitar bagian kaki bukit. Sumber mata air tersebut dikenal dengan nama Tuk. Namun besarnya Tuk sangat bervariasi, tergantung debit air tanah yang mengalir dan muncul ke permukaan kaki kaki bukit. ${ }^{3)}$

Di desa Kanigoro dan sekitarnya, dikenal beberapa Tuk, seperti Tuk Wangi, Tuk Ngerowo, Tuk Sedisin dan Tuk Blondo. Dari bak penampung masing-masing Tuk, dilakukan pemipaan untuk didistribusikan ke masing masing Dusun dusun setempat. ${ }^{3)}$

\subsection{Tujuan}

Studi ini bertujuan untuk memperoleh gambaran kualitas air permukaan di pedesaan dengan aktifitas budidaya pertanian intensif.

\section{METODOLOGI}

\subsection{Lokasi Pengambilan Contoh Air}

Contoh air permukaan diambil pada beberapa lokasi di Desa Kanigoro dan sekitarnya, sebagai berikut :

Kode Lokasi

$1=$ Tuk Wangi

$2=$ Kubangan di atas Tuk Wangi

$4=$ Bak air Desa Kenanggan

$5=$ Kali Suko

$6=$ Tuk Putuan

$8=$ Tuk Sedisin

$9=$ Sumur Dusun Pete

$11=$ Sumur Dusun Pete

$12=$ Sumur Dusun Pete

$13=$ Sumur Dusun Pete

$14=$ Bak pembagi Dusun Kanigoro

$19=$ Sumur jetpump Dusun Kanigoro
$20=$ Tuk Blondo (Dusun Karang Senden)

$22=$ Tuk Seseh (bak penampung)

$25=$ Tuk Ngrowo

$27=$ Ndempel

28= Sumur Pk Ngadri (Dusun Bandungrejo

Penetapan lokasi pengambilan sampel tersebut dilakukan berdasarkan kriteriakriteria sebagai berikut :

a. Lokasi contoh air merupakan sumber air bersih bagi masyarakat di Desa Kanigoro secara umum dan atau

b. Lokasi contoh air masih termasuk dalam DAS yang diperkirakan masih memiliki peran dalam suplai air bersih ke Desa Kanigoro dan atau

c. Sumur yang mewakili aliran air tanah yang menuju maupun berada di kawasan Desa Kanigoro

Lokasi pengambilan contoh air diatas dapat dilihat pada peta yang disajikan pada Gambar 3.

\subsection{Parameter Kualitas Air}

Untuk mengetahui status toksisitas air di Wilayah Studi, air sampel dianalisa di Laboratorium untuk parameter kualitas air dan sebagai contoh beberapa parameter utama tercantum pada Tabel 1

Tabel 1. Beberapa Parameter Kualitas Air yang di Analisa

\begin{tabular}{|l|l|l|}
\hline No. & Parameter & Unit \\
\hline 1. & Logam Berat & $\mathrm{mg} / \mathrm{L}$ \\
\hline 2. & Pestisida & $\mathrm{mg} / \mathrm{L}$ \\
\hline 3. & Mikrobiologi & $\mathrm{m}$ ind $/ \mathrm{ml}$ \\
\hline
\end{tabular}

\subsection{Analisa Kualitas Air}

Data hasil analisa Laboratorium selanjutnya dianalisis secara deskriptif dengan mempertimbangkan Peraturan Pemerintah No. 82 tahun 2001 tentang pengelolaan kualitas 
air dan pengendalian pencemaran air serta Peraturan Menteri Kesehatan No. 416 tahun 1990. ${ }^{8,9,10)}$ Acuan baku mutu yang digunakan adalah persyaratan kualitas air bersih dari PerMenKes dan persyaratan kualitas air baku golongan Kelas I, PP 82/2001 (Tabel 2.).

\section{HASIL DAN PEMBAHASAN}

Dari hasil pemeriksaan Laboratorium terhadap kualitas air di daerah kajian, parameter kualitas air baik parameter logam berat, pestisida dan parameter mikroba, sebagaimana disajikan pada Tabel 3, 4 dan 5 dikaji berdasarkan standar baku mutu air, baik Peraturan Pemerintah Nomor 82 Tahun 2001 maupun PerMenKes 416 Thn 1990 (Tabel2).

\subsection{Logam Berat}

Beberapa logam, seperti Arsen (As), Tembaga (Cu), Kadmium (Cd), Besi (Fe), Air Raksa (Hg), Timbal (Pb) dan Seng $(\mathrm{Zn})$ kadang digunakan dalam budidaya pertanian. Namun pemanfaatan yang berlebih di lahan pertanian akan mengakibatkan pencemaran lahan dan selanjutnya akan masuk perairan atau aliran air. Oleh karena itu, sehubungan dengan porositas tanah yang tinggi di desa Kanigoro dan sekitarnya, maka masuknya polutan kedalam air tanah dikawatirkan akan dengan mudah tersebar ke seluruh wilayah Desa Kanigoro dan sekitarnya mengikuti arah aliran air tanah sebagaimana ditampilkan pada peta Gambar $2^{33}$

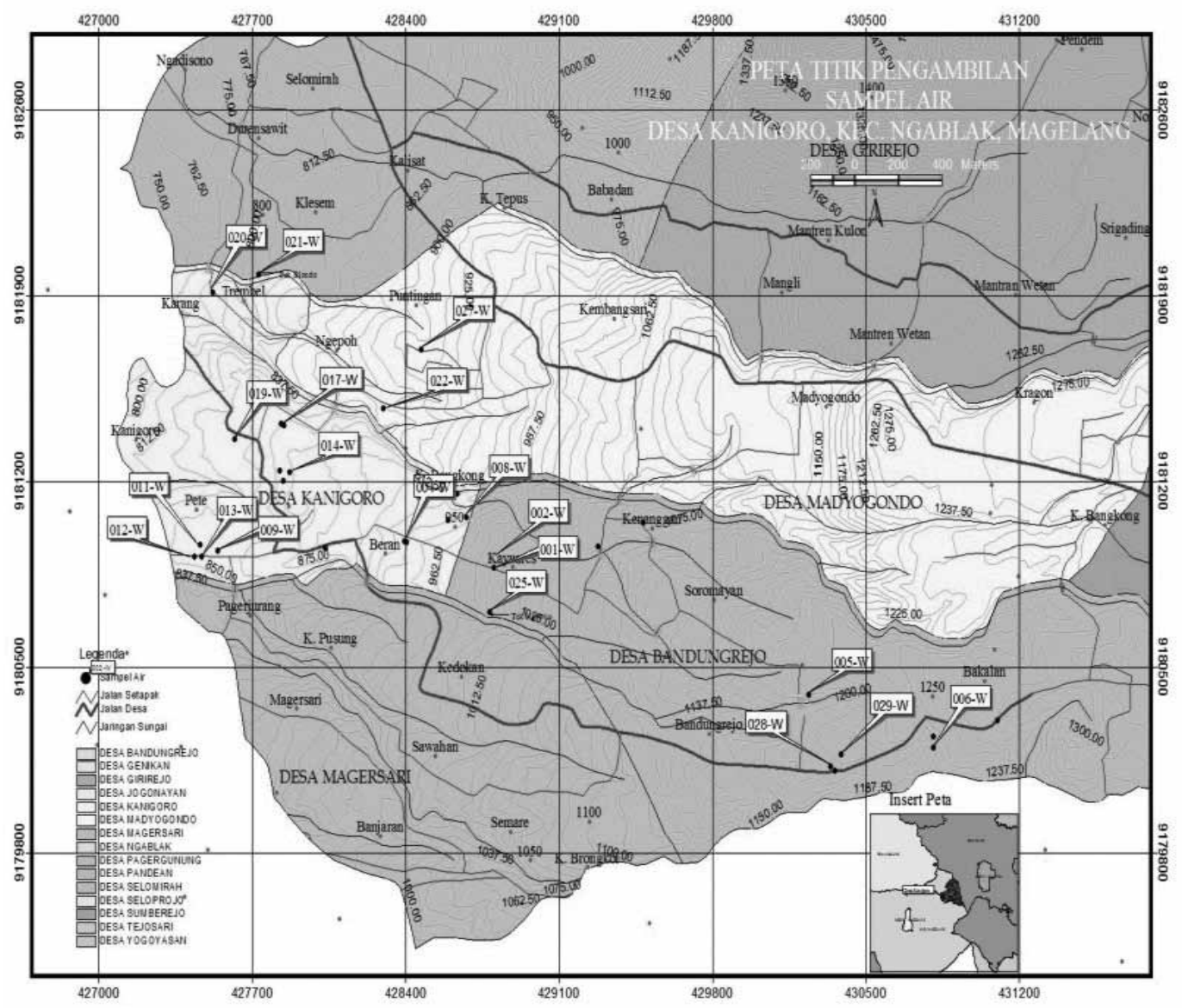

Gambar 3. Stasiun Pengukuran Kualitas Air Desa Kanigoro dan Sekitarnya 
Selanjutnya, meskipun keadaan cemaran logam tersebut di dalam air berkadar cukup rendah, dikawatirkan dalam waktu yang lama dapat terakumulasi di dalam biota air, antara lain ikan dan algae. ${ }^{14)}$

Sebenarnya, logam berat terbagi ke dalam dua jenis yaitu: pertama, logam berat esensial dimana keberadaannya dalam jumlah tertentu sangat dibutuhkan oleh setiap organisme hidup, seperti antara lain, seng $(\mathrm{Zn})$, tembaga $(\mathrm{Cu})$, besi $(\mathrm{Fe})$, kobalt (Co), mangaan (Mn) dan lain-lain. Kedua, logam berat tidak esensial atau beracun, dimana keberadaan dalam tubuh organisme hidup hingga saat ini masih belum diketahui manfaatnya bahkan justru dapat bersifat racun, seperti misalnya; merkuri $(\mathrm{Hg})$, kadmium $(\mathrm{Cd})$, timbal $(\mathrm{Pb})$, kromium $(\mathrm{Cr})$ dan lain-lain. ${ }^{11)}$

Logam berat esensial biasanya tebentuk sebagai bagian integral dari sekurang-kurangnya dengan satu jenis enzim. Walupun logam berat esensial dibutuhkan oleh setiap organisme hidup, namun dalam jumlah yang berlebihan dapat menimbulkan efek racun. ${ }^{11,12)}$

Kekawatiran adanya kandungan logam berat yang melebihi ambang batas baku mutu sangat beralasan, mengingat kandungan logam berat yang melebihi ambang batas akan menimbulkan dampak negatif kepada kesehatan penduduk setempat. ${ }^{11,14)}$

Sebagaimana diketahui bahwa beberapa logam berat mempunyai efek racun yang fatal bilamana terpapar kedalam air yang akan terminum atau termakan oleh manusia. Hal lain, akumulasi logam berat pada kehidupan perairan akan berbahaya bilamana dikonsumsi oleh manusia. ${ }^{11,13,14)}$

Selanjutnya, secara umum hasil analisis laboratorium terhadap sampel dari beberapa lokasi, baik sebagai sumber mata air (Tuk Wangi, Tuk Sedisin, Tuk Ngrowo, Tuk Blondo di Desa Kanigoro dan Tuk Puluan serta Tuk Seseh di Desa Bandung Rejo menunjukkan kandungan parameter masih memenuhi baku mutu kualitas air bersih (DepKes) dan air baku Kelas I (PP
82/2001) untuk parameter AS, CU, Cd, Fe, $\mathrm{Hg}$ dan Zn (Tabel 3.). Sedangkan untuk parameter Timbal $(\mathrm{Pb})$ hampir semua sampel menunjukkan konsentrasi $>0.05 \mathrm{mg} / \mathrm{L}$ (Tabel 3.), yang artinya sudah melebihi standar baku mutu kualitas air bersih DEPKES $(0.05 \mathrm{mg} / \mathrm{L})$ meskipun masih lebih rendah dari standar baku mutu Kelas IV PP 82/2001 (1 mg/L), kecuali Tuk Wangi, Tuk Sedisin dan bak penampung air di Dusun Kenanggan Desa Bandung Rejo. mengandung timbal masih dibawah ambang standar baku mutu (Tabel 2).

Tabel 2. Standar Bakumutu Beberapa Parameter Kualitas Air

\begin{tabular}{|c|c|c|}
\hline \multirow{2}{*}{ Parameter } & PerMenKes & PP82/2001 \\
\hline & Air Bersih & Kelas I \\
\hline Logam Berat & $\mathrm{ppm}$ & $\mathrm{ppm}$ \\
\hline $\operatorname{Kadmium}(\mathrm{Cd})$ & 0,005 & 0,01 \\
\hline Krom (Cr) & 0,05 & $0,01-0,05$ \\
\hline Tembaga $(\mathrm{Cu})$ & $?$ & 0,02 \\
\hline Merkuri $(\mathrm{Hg})$ & 0,001 & $0,001-0,005$ \\
\hline Seng $(Z n)$ & 15,0 & $0,05-2$ \\
\hline Timbal (Pb) & 0,05 & $0,03-1,0$ \\
\hline Arsen (As) & 0.05 & $0.05-1$ \\
\hline Besi (Fe) & 1.0 & 0.03 \\
\hline Pestisida & ppm & $\operatorname{Ppb}(\square g / l)$ \\
\hline $\mathrm{BHC}$ & 0,00001 & 210 \\
\hline Aldrin/Dieldrin & 0,0007 & $0-17$ \\
\hline Chlordane & & $0-3$ \\
\hline DDT & 0,03 & 2 \\
\hline Heptachlor & 0,003 & $0-18$ \\
\hline Lindane & 0,004 & $0-56$ \\
\hline Methoxychlor & 0,03 & $0-35$ \\
\hline Endrin & & $1-4$ \\
\hline Toxaphene & & $0-5$ \\
\hline Mikroba & $(\mathrm{jmlh} / 100 \mathrm{~mL})$ & $(\mathrm{jmlh} / 100 \mathrm{~mL})$ \\
\hline Koliform Tinja & 0 & 100 \\
\hline Total Koliform & 0 & 1000 \\
\hline
\end{tabular}

Sumber :PerMenKes No416 Thn 1990 dan PP No.82 Thn 2001 
Dari peta sebaran sampel dikaitkan dengan kandungan $\mathrm{Pb}$, ada semacam kecenderungan bahwa sumber air dibagian hulu Desa Kanigoro terpapar oleh $\mathrm{Pb}$ termasuk air di bak penampung dan sumur di Desa Kanigoro, kecuali tuk Wangi dan Tuk Sedisin.

Di perairan, timbal $(\mathrm{Pb})$ biasanya terakumulasi pada organisme perairan melalui rantai makanan dan uptake langsung. Timbal dipastikan dapat menyebabkan hipertensi, mengacaukan sistem organ reproduksi, saraf dan metabolisme. ${ }^{14)}$

Namun demikian kandungan logam berat air permukaan di Desa Kanigoro masih layak untuk penggunaan pemanfaatan untuk pertanian serta perikanan, kecuali untuk kebutuhan domestik diperlukan pengolahan terlebih dahulu.

Selamainidalam pengelolaan lingkungan hidup pandangan kita bersifat antroposentris, yaitu melihat permasalahannya hanya dari sudut kepentingan manusia saja. Manusia berinteraksi dengan lingkungan hidupnya karena ia mempengaruhi dan dipengaruhi oleh lingkungan hidupnya. Oleh karena itu, pengelolaan lingkungan harus bersifat holistik, yaitu memandang keseluruhannya sebagai suatu kesatuan (Soemarwoto, 1997). ${ }^{15)}$

\section{Pestisida}

Sesuai terminologi yang dikeluarkan oleh FAO (1986) dan Peraturan Pemeriantah No.7 Tahun 1973, pestisida adalah merupakan campuran bahan kimia digunakan untuk pencegahan, pembasmian dan pengendalian hewan pengganggu dan atau tumbuhan pengganggu dengan tujuan kesejahteraan manusia. ${ }^{11,12)}$

Secara umum, pestisida dikelompokan sebagait:(a) organoklorin, (b) organo-fosfat/ karbamat dan (c) piretroid. Khusunya kelompok organo-klorin, pestisida ini peredarannya di negara sedang berkembang sangat luas dibandingkan dengan pemanfaataan dinegara maju. ${ }^{11)}$
Kandungan pestisida dalam air dapat terjadi, karena adanya kegiatan pembangunan yang memanfaatkan pestisida dalam prosesnya. Paparan tersebut dikawatirkan bila masuk atau larut di badan air akan diserap oleh organisma lain seperti tumbuhan dan hewan air yang pada akhirnya dimanfaatkan oleh manusia. ${ }^{12,13)}$

Namun demikian, meskipun kegiatan budidaya pertanian di Desa Kanigoro dan desa lainnya sangat intensif menggunakan pestisida, hasil analisa laboratotium menunjukkan kandungan pestisida pada contoh air tidak terdeteksi (<0.5 ppm) sebagaimana disajikan pada Tabel 4 tidak menunjukkan konsentrasi yang melebihi standar baku mutu parameter pestisida.9,10)

Padahal desa Kanigoro dan sekitarnya merupakan daerah pertanian, seperti tanaman holtikultur dan tanaman setahun yang secara regular diberikan pemupukan dan pencegahan hama dengan pestisida.

\subsection{Parameter Mikroba}

Parameter kualitas air yang masih melebihi baku mutu air adalah tingginya populasi mikroba coli pada air sampel. Menurut acuan Peraturan Menteri Kesehatan, bahwa air minum dan air bersih harus tidak mengandung mikroba total coliform dan fekal coli, meskipun menurut Peraturan Pemerintah No.82 thn 2001, adanya mikroba tersebut dalam jumlah tertentu masih dapat ditolerir. ${ }^{9,10}$ Hasil pengukuran kepadatan mikroba Total Koliform pada Tabel 5 menunjukkan hampir semua sample air mengandung mikroba tersebut melebihi baku mutu untuk air bersih (DepKes) juga PP 82/2001 untuk semua golongan Kelas I s/d IV.10)

Dengan demikian hasil pemeriksaan sampel air mengindikasikan bahwa sumber air tersebut sangat subur untuk pertumbuhan bakteri pathogen. Untuk lebih menguatkan indikasi ini, hasil penghitungan koliform tinja disajikan pada Tabel 5.

Data pada Tabel 5 menunjukkan bahwa 
Sumur-sumur di Dusun Pete(11, 12, 13), Bak pembagi di Dusun Kanigoro (14), Sumur jetpump di Dusun Kanigoro (19), Tuk Blondo Dusun Karang Senden (20), bak penampung Tuk Seseh (22), Tuk Ngrowo (25) dan Sumur di Dusun Bandungrejo (28) tidak terdeteksi mengandung mikroba koliform tinja. Informasi ini menunjukkan bahwa sumber air tersebut hanya terkontaminasi koliform dari sumber bukan manusia.

Sebaliknya sampel air dari sumber air di Tuk Wangi (1) dan Kubangan di atas Tuk Wangi (2), Bak air Desa Kenanggan (4), Kali Suko (5), 6 = Tuk Puluan (6), Tuk Sedisin (8), Sumur Dusun Pete (9) mengindikasikan diatas baku mutu air bersih (DepKes) dan Baku mutu air baku Kelas I, PP 82/2001. ${ }^{10)}$

Kepadatan mikroba koli tersebut mengindikasikan bahwa sanitasi lingkungan di Desa sampel masih perlu diperbaiki, untuk mencegah penyebaran penyakit akibat

Tabel 5. Jumlah Coliform dan E. Coli dalam Sampel air

\begin{tabular}{|c|c|c|c|}
\hline No. & $\begin{array}{c}\text { Kode } \\
\text { sampel }\end{array}$ & $\begin{array}{c}\text { Jumlah } \\
\text { coliform } \\
(\text { sel/100ml) }\end{array}$ & $\begin{array}{c}\text { Jumlah E.Coli } \\
\text { (Cfu/100ml) }\end{array}$ \\
\hline 1 & 1 & $3.30 \times 104$ & $0.50 \times 102$ \\
\hline 2 & 2 & $7.90 \times 104$ & $3.50 \times 102$ \\
\hline 3 & 4 & $1.70 \times 104$ & $7.00 \times 102$ \\
\hline 4 & 5 & $7.90 \times 104$ & $6.20 \times 103$ \\
\hline 5 & 6 & $2.20 \times 104$ & $2.05 \times 103$ \\
\hline 6 & 8 & $3.30 \times 104$ & $3.50 \times 102$ \\
\hline 7 & 9 & $1.40 \times 104$ & $8.05 \times 103$ \\
\hline 8 & 11 & $0.68 \times 104$ & t.t \\
\hline 9 & 12 & $2.10 \times 104$ & t.t \\
\hline 10 & 13 & $3.50 \times 105$ & t.t \\
\hline 11 & 14 & $1.70 \times 105$ & t.t \\
\hline 12 & 19 & $7.90 \times 104$ & t.t \\
\hline 13 & 20 & $7.00 \times 104$ & t.t \\
\hline 14 & 22 & $0.40 \times 104$ & t.t \\
\hline 15 & 25 & $0.20 \times 104$ & t.t \\
\hline 16 & 27 & $5.40 \times 105$ & $2.60 \times 103$ \\
\hline 17 & 28 & $4.90 \times 104$ & \\
\hline & & & \\
\hline
\end{tabular}

bakteri patogen, bila suatu saat jumlah mikrobanya semakin meningkat.

Selanjutnya fasilitas jamban keluarga yang masih berbentuk cubluk, sementara tanah di Desa Kanaigoro memiliki porositas tinggi, sehingga infiltrasi air limbah dikawatirkan dapat mencemari dengan cepat sumber air yang tersedia. ${ }^{3)}$

Salah satu upaya adalah memberikan bimbingan masyarakat untuk memperbaiki fasilitas sumber air, meningkatkan sistem sanitasi lingkungan (MCK) dan untuk pencegahan penggunaan keluarga, air minum harus dimasak terlebih dahulu.

\section{PENUTUP}

Hasil analisis menunjukkan bahwa kualitas air Desa Kanigoro adalah sebagai berikut :

1 Hasil analisis parameter logam berat dan pestisida sampel air, pada umumnya masih memenuhi standar baku mutu yang berlaku, kecuali untuk beberapa titik mengandung logam berat $\mathrm{Pb}$ melebihi standar baku mutu air bersih DepKes dan Baku mutu Kelas I (air baku) PP 82/2001.

2 Sebagian besar contoh air, menunjukkan kepadatan mikroba total coliform dan E. Coli yang melimpah melebihi ketentuan Peraturan Menteri Kesehatan, khususnya untuk penggunaan air sebagai air baku atau air bersih. Namun demikian kondisi air ini masih dimungkinkan untuk penggunaan pertanian dan budidaya ikan serta penggunaan untuk air minum setelah dimasak terlebih dahulu.

\section{DAFTAR PUSTAKA}

1. Anonim. 2005. Kabupaten Magelang dalam Angka. Badan Pusat Statisitk Kabupaten Magelang

2. Bakosurtanal. 2000. Peta Rupabumi Digital Indonesia 1:25.000. Lembar 1408522 Ngablak. Bakosurtanal, Bogor. 
3. Anonim. 2007. Pemulihan Kualitas Lingkungan Desa Kanigoro-Ngablak, Kabupaten Magelang. Pusat Teknologi Ligkungan - Badan Pengkajian Dan Penerapan Teknologi. Jakarta.

4. Yuantari, M G C. 2009. Studi Ekonomi Lingkungan Penggunaan Pestisida dan Dampaknya pada Kesehatan Petani di Area Pertanian Hortikultura Desa Sumber Rejo Kecamatan Ngablak Kabupaten Magelang. Program Pascasarjana UNDIP, Semarang. Tesis:124pp. http://eprints.undip. ac.id/18103/1/MARIA_GORETTI_ CATUR_YUANTARI.pdf

5. Prijanto, TB. 2009. Analisis Faktor Risiko Keracunan Pestisida Organofosfat pada Keluarga Petani Hortikultura di Kecamatan Ngablak Kabupaten Magelang. Program Pascasarjana UNDIP, Semarang. Tesis:120pp.http:// eprints.undip.ac.id/17895/1/TEGUH_ BUDI_PRIJANTO.pdf

6. Runia Y A. 2008. Faktor-Faktor yang Berhubungan dengan Keracunan Pestisida Organofosfat, Karbamat, dan Kejadian Anemia pada Petani Hortikultura di Desa Tejosari Kecamatan Ngablak Kabupaten Magelang. Program Pascasarjana UNDIP, Semarang. Tesis:92pp. http://eprints. undip.ac.id/17532/1/YODENCA ASSTI_RUNIA.pdf

7. Arifin, M.B. dan E. Murtianto. 1999. Penyelidikan Potensi Cekungan Air Bawah Tanah Magelang-Temanggung, Jawa Tengah. Direktorat Geologi Tata
Lingkungan, Bandung.

8. APHA, 1976. Standart Methods for the Examination of water and Wastewater. 4th edition. Amirican Public Health Association, Washington DC. 1193 p.

9. Anonim.1990. Peraturan Menteri Kesehatan RI No. 416/Menkes/IX/1990 tentang syarat-syarat dan pengawasan kualitas air minum, Berita Negara RI 1990. Departemen Kesehatan RI.

10. Anonim. 2001. Peraturan Pemerintah Nomor 82 Tahun 2001 tentang Pengelolaan Kualitas Air Dan Pengendalian Pencemaran Air. Sekretariat Negara RI.

11. Slamet, J.S. 2003. Toksikologi Lingkungan. Penerbit Gajah Mada University Prress. ISBN 979-420-533-8

12. Slamet, J.S. 2004. Kesehatan Lingkungan. Penerbit Gajah Mada University Prress. ISBN 979-420-309-2

13. Sudarmaji, J.Mukono dan I.P Corie. 2006. Toksikologi Logam berat B3 dan dampaknya terhadap kesehatan. JURNAL KESEHATAN LINGKUNGAN, VOL. 2, NO. 2: $129-142$

14. Halang B. 2007. Kandungan Cu dan $\mathrm{Pb}$ pada air dan ikan puyau (Puntius huguenini) di bendungan sungai Tabaniao desa Bajuin Kecamatan Pelaihari Kabupaten Tanah Laut. BIOSCIENTIAE Volume 4, Nomor 1: 43-52. http://www.unlam.ac.id/ bioscientiae/

15. Soemarwoto O. 1997. Ekologi Lingkungan Hidup dan Pembangunan. Penerbit Jambatan. Jakarta 
Tabel 3. Hasil analisis laboratorium parameter logam berat

\begin{tabular}{|c|c|c|c|c|c|c|c|c|c|}
\hline Titik Penerokan & 1 & 2 & 4 & 5 & 6 & 8 & 9 & 11 & 12 \\
\hline \multicolumn{10}{|c|}{ Logam berat (mg/L) } \\
\hline As (arsen) & $<0,002$ & $<0,002$ & $<0,002$ & $<0,002$ & $<0,002$ & $<0,002$ & $<0,002$ & $<0,002$ & $<0,002$ \\
\hline Cu (tembaga) & $<0,01$ & $<0,01$ & $<0,01$ & $<0,01$ & $<0,01$ & $<0,01$ & $<0,01$ & $<0,01$ & $<0,01$ \\
\hline Cd (kadmium) & $<0,01$ & $<0,01$ & $<0,01$ & $<0,01$ & $<0,01$ & $<0,01$ & $<0,01$ & $<0,01$ & $<0,01$ \\
\hline Fe (besi) & $<0,05$ & $<0,05$ & $<0,05$ & $<0,05$ & $<0,05$ & $<0,05$ & 0,72 & $<0,05$ & $<0,05$ \\
\hline $\mathrm{Hg}\left(\right.$ air raksa) ${ }^{*}$ & $<0,2$ & $<0,2$ & $<0,2$ & $<0,2$ & $<0,2$ & $<0,2$ & $<0,2$ & $<0,2$ & $<0,2$ \\
\hline $\mathrm{Pb}$ (timbal) & $<0,01$ & $<0,01$ & $<0,01$ & 0,09 & 0,23 & $<0,01$ & 0,05 & 0,28 & 0,07 \\
\hline Zn (seng) & $<0,01$ & $<0,01$ & 0,01 & 0,01 & 0,01 & 0,01 & 0,02 & 0,01 & 0,01 \\
\hline
\end{tabular}

\begin{tabular}{|l|r|r|r|r|r|r|r|r|r|}
\hline Titik Penerokan & 13 & 14 & 19 & 20 & 22 & 25 & 27 & 28 & $\begin{array}{c}\text { QA/ } \\
\text { QC }\end{array}$ \\
\hline Logam berat (mg/L) & & & & & & & \\
\hline As (arsen) & $<0,002$ & $<0,002$ & $<0,002$ & $<0,002$ & $<0,002$ & $<0,002$ & $<0,002$ & $<0,002$ & $<0,002$ \\
\hline $\mathrm{Cu}$ (tembaga) & $<0,01$ & $<0,01$ & $<0,01$ & $<0,01$ & $<0,01$ & $<0,01$ & $<0,01$ & $<0,01$ & $<0,01$ \\
\hline $\mathrm{Cd}$ (kadmium) & $<0,01$ & $<0,01$ & $<0,01$ & $<0,01$ & $<0,01$ & $<0,01$ & $<0,01$ & $<0,01$ & $<0,01$ \\
\hline $\mathrm{Fe}$ (besi) & 0,07 & 0,09 & $<0,05$ & $<0,05$ & $<0,05$ & $<0,05$ & $<0,05$ & $<0,05$ & $<0,05$ \\
\hline $\mathrm{Hg}$ (air raksa) & $<0,2$ & $<0,2$ & $<0,2$ & $<0,2$ & $<0,2$ & $<0,2$ & $<0,2$ & $<0,2$ & $<0,2$ \\
\hline $\mathrm{Pb}$ (timbal) & 0,34 & 0,40 & 0,18 & 0,43 & 0,07 & 0,12 & 0,27 & 0,15 & $<0,01$ \\
\hline $\mathrm{Zn}$ (seng) & 0,01 & 0,02 & 0,01 & 0,01 & 0,01 & 0,01 & 0,35 & 0,02 & 0,01 \\
\hline
\end{tabular}

Keterangan :*Satuan untuk air raksa adalah $\mathrm{DgL}-1$

Tabel 4. Hasil analisis laboratorium parameter pestisida

\begin{tabular}{|l|r|r|r|r|r|}
\hline Titik Penerokan & 1 & 9 & 11 & 12 & 19 \\
\hline Pestisida ( $\square \mathrm{g} / \mathrm{L})$ & \multicolumn{7}{|c|}{1} \\
\hline Aldrin & $<0,01$ & $<0,01$ & $<0,01$ & $<0,01$ & $<0,01$ \\
\hline BHC & $<0,01$ & $<0,01$ & $<0,01$ & $<0,01$ & $<0,01$ \\
\hline Chlordane & $<0,01$ & $<0,01$ & $<0,01$ & $<0,01$ & $<0,01$ \\
\hline DDT & $<0,01$ & $<0,01$ & $<0,01$ & $<0,01$ & $<0,01$ \\
\hline Dieldrin & $<0,01$ & $<0,01$ & $<0,01$ & $<0,01$ & $<0,01$ \\
\hline Endrin & $<0,01$ & $<0,01$ & $<0,01$ & $<0,05$ & $<0,05$ \\
\hline Heptachlor & $<0,01$ & $<0,01$ & $<0,01$ & $<0,01$ & $<0,01$ \\
\hline Heptachlor epoxide & $<0,01$ & $<0,01$ & $<0,01$ & $<0,01$ & $<0,01$ \\
\hline Lindane & $<0,01$ & $<0,01$ & $<0,01$ & $<0,01$ & $<0,01$ \\
\hline Methoxychlor & $<0,02$ & $<0,02$ & $<0,02$ & $<0,2$ & $<0,2$ \\
\hline Toxaphene & $<0,02$ & $<0,02$ & $<0,02$ & $<0,2$ & $<0,2$ \\
\hline
\end{tabular}

